\title{
Arbuscular mycorrhizal fungi associations of vascular plants confined to river valleys: towards understanding the river corridor plant distribution
}

\author{
Agnieszka Nobis · Janusz Błaszkowski • Szymon Zubek
}

Received: 6 March 2014 / Accepted: 29 August 2014 / Published online: 25 November 2014

(C) The Author(s) 2014. This article is published with open access at Springerlink.com

\begin{abstract}
The group of river corridor plants (RCP) includes vascular plant species which grow mainly or exclusively in the valleys of large rivers. Despite the long recognized fact that some plant species display a corridorlike distribution pattern in Central Europe, there is still no exhaustive explanation of the mechanisms generating this peculiar distribution. The main goal of this study was therefore to investigate whether arbuscular mycorrhizal fungi (AMF) and fungal root endophytes influence the RCP distribution. Arbuscular mycorrhizae (AM) were observed in 19 out of 33 studied RCP. Dark septate endophytes (DSE) and Olpidium spp. were recorded with low abundance in 15 and 10 plant species, respectively. The spores of AMF were found only in $32 \%$ of trap cultures established from the soils collected in the river corridor habitats. In total, six widespread AMF species were identified. Because the percentage of non-mycorrhizal species in the group of RCP is significant and the sites in river corridors are characterized by low AMF species diversity, RCP can be outcompeted outside river valleys by the widespread species that are able
\end{abstract}

Electronic supplementary material The online version of this article (doi:10.1007/s10265-014-0680-9) contains supplementary material, which is available to authorized users.

A. Nobis $\cdot$ S. Zubek $(\bowtie)$

Department of Plant Taxonomy, Phytogeography and Herbarium, Institute of Botany, Jagiellonian University, Kopernika 27,

31-501 Kraków, Poland

e-mail: szymon.zubek@uj.edu.pl

A. Nobis

e-mail: agnieszka.nobis@uj.edu.pl

J. Błaszkowski

Department of Plant Protection, West Pomeranian University of Technology, Słowackiego 17, 71-434 Szczecin, Poland e-mail: janusz.blaszkowski@zut.edu.pl to benefit from AM associations in more stable plant-AMF communities in non-river habitats.

Keywords Arbuscular mycorrhizal fungi (AMF) . Central Europe $\cdot$ Dark septate endophytes (DSE) $\cdot$ Linear distribution pattern of vascular plants - Olpidium spp. Plant geography

\section{Introduction}

As early as in the second half of the nineteenth century German phytogeographers noticed that some vascular plant species demonstrate specific linear distribution pattern reflecting their confinement to river valleys (e.g. Ascherson 1859; Loew 1879). Burkart (2001) proposed the English term 'river corridor species' for this group of plants and presented the first preliminary list of 129 species growing mainly or exclusively in the corridors of large rivers in Central Europe. The list was recently supplemented by Nobis and Skórka (2014). Confinement of the particular species to river corridors can be estimated by calculation of its river corridor-specificity index (RCSI). The index calculation procedure is included in the works by Fischer et al. (2010) and Nobis and Skórka (2014).

Different hypotheses have been proposed to explain the phenomenon in question. Ascherson (1859) and Loew (1879) supposed that in the case of river corridor plants (RCP) water is the most important vector of their propagules. Therefore, they believed that hydrohory explains their linear distribution pattern. In fact, there is little evidence supporting this hypothesis (Andersson and Nilsson 2002; Nilsson et al. 2010; Nobis and Skórka 2014). A second probable explanation of the unique distribution pattern is typical of floodplain ecosystems disturbance by 
water resulting in a complete or partial reduction in plant cover (Jentsch and Seitz 1997; Vent and Benkert 1984). The published data confirm significance of disturbance in corridor-like distribution of some alien and native vascular plant species (Andres and Westhus 2000; Burkart 1995; Pyšek and Prach 1994). According to the climatic hypothesis, the occurrence of warmer summer conditions in river valleys than in their surroundings is an important factor for RCP distribution (Müller-Stoll et al. 1962; Vent and Benkert 1984). Finally, differences in nutrient supply in floodplains and in their surrounding areas suggest that RCP may require high nutrition levels (Fischer 1996; Vent and Benkert 1984). According to Nobis and Skórka (2014), who analyzed ecological features of RCP using the Ellenberg's system of indicator values, corridor species differ from widespread species (i.e. species which do not show confinement to river corridors and are very frequent in the area of Poland) in several traits, with requirements for a higher temperature and alkalinity being the most distinctive features of the former. However, no significant difference in the nutrient requirements between the two groups of plants has been observed.

River corridor distribution patterns are not only affected by different abiotic environmental factors. Propagule transport by birds migrating along the river valleys turned out to be important for some RCP (e.g. Gams 1927). Moreover, Hensgen et al. (2011) indicated that the distribution of some RCP may be influenced by gastropods. It cannot be excluded that also other groups of organisms can influence the plants confined to river valleys. Among soil microorganisms, arbuscular mycorrhizal fungi (AMF) play a key role in the impact on plant performance. They have been found to influence the growth, vitality, reproduction and survival rate of plants as well as determine plant community structure (Perotto et al. 2013; Smith and Read 2008). As no studies focused on mycorrhiza associations of the group of plants in question have been performed so far, the aim of the present study was therefore to investigate their arbuscular mycorrhiza (AM) status, the degree of root colonization by AMF and to evaluate AMF species diversity in soils surrounding roots of plants demonstrating corridorlike distribution in Poland.

Winter, spring and early summer floods typical of river corridors may result not only in a complete or partial reduction in plant cover, but can also affect soil microorganism consortia, including AMF. On the other hand, summer in the river valleys is notably dry, so the microorganisms inhabiting river corridor soils are influenced by very variable soil moisture. We therefore expected that plant species confined to river corridors form arbuscular mycorrhiza (AM) rarely or not at all, or the degree of colonization of their roots is low due to the lack or low number of AMF species and their propagules in river corridor soils. We put forward the hypothesis that RCP are consequently outcompeted outside river valleys by the widespread species that are able to benefit from AM associations in more stable plant-AMF communities in non-river habitats.

\section{Materials and methods}

Study area and material sampling

The material was collected in 2011 and 2012 in the lower course of the San River Valley (Fig. S1). San River is situated in southeastern Poland and western Ukraine. It is a right-bank tributary of the Vistula River. With its length of $443 \mathrm{~km}$ it is the 6th-longest Polish river. Lower San River Valley comprises many natural and semi-natural ecosystems. It is therefore considered as very valuable for biodiversity conservation. A significant part of the Lower San River Valley is protected as a Special Area of Conservation (SACs) established under NATURA 2000. In the study area the following habitats can be found: muddy river banks, watercourse veils, reed beds, riverine willow scrub, aluvial forests, meadows, dry grasslands, oxbow lakes, herbaceous fringes, pastures and arable fields. Many of the listed habitats are suitable for vascular plants which are included in the list of RCP of Poland proposed by Nobis and Skórka (2014).

Altogether, 33 RCP species from 100 randomly selected locations (3, rarely 2 or 4 sites per species) were collected during flowering or early seed formation period mostly from typical habitats. The roots of each collected specimen were excavated with surrounding soil. The root systems, or their fragments, were then placed in plastic containers holding $50 \%$ ethanol in water. The soil samples were dried at room temperature of around $22{ }^{\circ} \mathrm{C}$. The list of all studied species together with the data on the name and coordinates of localities as well as the habitats where their specimens were collected are presented in the supplementary material (Table S1). The nomenclature of vascular plant species follows Mirek et al. (2002).

Root staining and the assessment of fungal colonization

The roots were prepared in accordance with the modified Phillips and Hayman (1970) method. They were cleared in $10 \% \mathrm{KOH}$ for $24 \mathrm{~h}$ and then rinsed in water. The material was then acidified in $5 \%$ lactic acid in water $(24 \mathrm{~h})$, stained with $0.05 \%$ aniline blue in $80 \%$ lactic acid $(72 \mathrm{~h})$, and finally stored in $80 \%$ lactic acid until analyzed. Root fragments approximately $1 \mathrm{~cm}$ long, at 30 fragments per one repetition sample, were mounted on slides in glycerol:lactic acid $(1: 1)$ and pressed using coverslides. 
Fungal root colonization was assessed by means of a Nikon Eclipse 80i light microscope with differential interference contrast (DIC). AMF colonization and morphology were identified on the basis of hyphae growing (a) intercellularly, forming arbuscules terminally in cortical cells (the Arum-type of AM morphology); (b) intracellularly with arbuscules developed on coils in cortical cells (Paris-type); or (c) forming intermediate types (Dickson 2004). The method proposed by Trouvelot et al. (1986) was followed for the assessment of the degree of AM development. The parameters evaluated were mycorrhizal frequency, relative mycorrhizal root length, and relative arbuscular richness. An estimate of the mycorrhizal frequency $\left(\mathrm{F}_{\mathrm{AMF}} \%\right)$ is given as the ratio between root fragments colonized by AMF mycelium and the total number of root fragments analysed. The relative mycorrhizal root length $\left(\mathrm{M}_{\mathrm{AMF}} \%\right)$ is an estimate of the amount of root cortex colonized by AMF relative to the entire root system investigated. The relative arbuscular richness $\left(\mathrm{A}_{\mathrm{AMF}} \%\right)$ is an estimate of arbuscule richness in the entire root system analysed (Trouvelot et al. 1986).

During the assessment of AMF colonization, we also observed fungal endophytes that accompanied AMF in roots, namely dark septate endophytes (DSE) and fungi from the genus Olpidium. DSE colonization was identified on the basis of regularly septate hyphae, usually dark pigmented, with facultatively occurring sclerotia (Jumpponen 2001). Additionally, the frequency of occurrence of Olpidium sporangia (Webster and Weber 2007) was assessed. In the case of DSE and Olpidium colonization, the frequency of the occurrence of the structures of these fungi in roots $\left(\mathrm{F}_{\mathrm{DSE}} \%, \mathrm{~F}_{\mathrm{Olp}} \%\right)$ was estimated as detailed above for AMF.

Because parameters specifying the degree of AM development $\left(\mathrm{F}_{\mathrm{AMF}} \%, \mathrm{M}_{\mathrm{AMF}} \%\right.$ and $\left.\mathrm{A}_{\mathrm{AMF}} \%\right)$ as well as the frequency of the occurrence of fungal root endophytes $\left(\mathrm{F}_{\mathrm{DSE}} \%\right.$ and $\left.\mathrm{F}_{\mathrm{Olp}} \%\right)$ and river corridor-specificity indexes (RCSI) did not meet the assumptions of normality, nonparametric tests were applied in statistical analyses. The relationships between root colonization of RCP species by AMF, DSE or Olpidium spp. and the river corridor-specificity index were analysed by means of Spearman's rank correlation coefficients. The statistical calculations were performed using the STATISTICA 10 software package.

\section{Establishment of the AMF trap cultures}

The soils excavated from under each plant species collected in 2012 were used to establish AMF trap cultures. For the establishment of each trap culture, $100 \mathrm{~g}$ of air-dried soil was placed in $9 \mathrm{~cm} \times 12.5 \mathrm{~cm}, 500 \mathrm{ml}$, plastic pots containing autoclaved, commercially available, coarse-grained sand. Plantago lanceolata was used as the host plant. In total, 56 trap cultures were established.
AMF spore isolation and identification

Ten months after establishment of the trap cultures, AMF spores were extracted using the wet sieving and decanting method of Gerdemann and Nicolson (1963). AMF species were identified according to Błaszkowski (2012). The shape and size of spores were determined from intact spores mounted in a drop of water or lactic acid on a microscope slide. Dimensions were determined using a compound microscope equipped with an ocular micrometer. The thickness of layers of a spore wall and inner walls was measured in material mounted on a slide in a drop of polyvinyl alcohol/lactic acid/glycerol (PVLG) and in a mixture of PVLG/Melzer's reagent (4:1, v/v) (Omar et al. 1979), and observed under a compound microscope equipped with micrometer eyepiece. Spore colour was determined in water and observed under a dissecting microscope. Colour of spore wall layers and inner wall layers was determined in spores crushed in PVLG, and in PVLG/Melzer's reagent when staining reactions were examined. Colours were determined according to Kornerup and Wanscher (1983). The observations of AMF spore features were performed using an Olympus BX51 light microscope with differential interference contrast (DIC). The fungal species and family names given in Table 1 are after Schüßler and Walker

Table 1 Arbuscular mycorrhizal fungi (AMF, Glomeromycota) isolated from the trap cultures established with the soils collected from the selected stations of river corridor plant species

\begin{tabular}{|c|c|c|}
\hline Fungal family & Fungal species & $\begin{array}{l}\text { River corridor plant } \\
\text { species }^{\mathrm{a}}\end{array}$ \\
\hline $\begin{array}{l}\text { Claroideoglomer- } \\
\text { aceae }\end{array}$ & $\begin{array}{l}\text { Claroideoglomus } \\
\text { claroideum } \\
\text { Claroideoglomus } \\
\text { drummondii }\end{array}$ & $\begin{array}{l}\text { Alisma lanceolatum }^{4} \\
\text { Myosotis sparsiflora }^{41} \\
\text { Aethusa cynapioides }^{2} \\
\text { Gratiola officinalis }^{28} \\
\text { Potentilla supina }^{45} \\
\text { Roripa austriaca }^{49,50}\end{array}$ \\
\hline Diversisporaceae & Diversispora sp. & Gratiola officinalis $^{28}$ \\
\hline Glomeraceae & Septoglomus constrictum & $\begin{array}{l}\text { Butomus umbelatus }^{8,9} \\
{\text { Cirsium } \text { canum }^{18}}^{\text {Myosotis sparsiflora }^{40}} \\
\text { Petasites spurius }^{44} \\
\text { Roripa austriaca }^{50} \\
\text { Viola stagnina }^{55,56}\end{array}$ \\
\hline & $\begin{array}{l}\text { Funneliformis mosseae } \\
\text { Rhizophagus irregularis }\end{array}$ & $\begin{array}{l}\text { Butomus umbelatus }{ }^{10} \\
\text { Aethusa cynapioides }\end{array}$ \\
\hline Paraglomeraceae & Paraglomus majewskii & $\begin{array}{l}\text { Potentilla supina } 46,47 \\
\text { Roripa austriaca }^{49}\end{array}$ \\
\hline
\end{tabular}

The superscript number indicates the location of isolation as listed in Table S1

a The name of plant species from which an AMF trap culture was isolated 
(2010), apart from Paraglomus majewskii and Septoglomus constrictum, which follows Błaszkowski et al. (2012) and Redecker et al. (2013), respectively.

Chemical soil analyses

Soil samples collected from under studied RCP species were air-dried and sieved $(<2 \mathrm{~mm})$. All the samples were analyzed for $\mathrm{pH}$ in aqueous solution. The total nitrogen $(\mathrm{N} \%)$ in soil samples was determined by means of the Kjeldahl method, and the organic carbon (C \%) using the Tiurin method (Mocek and Drzymała 2010). The assessment of plant-available phosphorus $\left(\mathrm{P}_{2} \mathrm{O}_{5}\right)$ and potassium $\left(\mathrm{K}_{2} \mathrm{O}\right)$ contents were done after extraction with ammonium lactate acetic acid according to Egner et al. (1960). Exchangeable cations $\left(\mathrm{K}^{+}\right.$, $\mathrm{Na}^{+}, \mathrm{Mg}^{2+}$ and $\mathrm{Ca}^{2+}$ ) were measured using a flame photometer and spectrophotometer in $1 \mathrm{~N}$ ammonium acetate.

Correlations between root colonization of RCP species by AMF, DSE and Olpidium spp. and particular site parameters were analysed using non-parametric Spearman rank correlation.

\section{Results}

Fungal root colonization of RCP species

Arbuscular mycorrhizae (AM) were observed in 19 out of the 33 studied RCP species. The mean values of mycorrhizal frequency parameter $\left(\mathrm{F}_{\mathrm{AMF}} \%\right)$ ranged from $37.7 \%$ in Lindernia procumbens to $100 \%$ in Allium scorodoprasum. In the case of relative mycorrhizal root length $\left(\mathrm{M}_{\mathrm{AMF}} \%\right)$, the mean values were lowest in Senecio fluviatilis (8.7\%) and highest in Allium scorodoprasum (87.3\%). Similar trends were also found in relative arbuscular richness $\left(\mathrm{A}_{\mathrm{AMF}} \%\right)$. The mean values of this parameter varied from $8.5 \%$ in Senecio fluviatilis to $85.8 \%$ in Allium scorodoprasum. Mycorrhizae of 12 plant species were of the Arum morphology, five taxa showed Paris-type of AM colonization, and both Arum and Paris morphology in the same root systems was found in two species (Table 2).

No AMF mycelium was found in the roots of 14 plant species. All species studied from Alismataceae, Brassicaceae, Caryophyllaceae, Chenopodiaceae, Cyperaceae, Equisetaceae and Poaceae families were non-mycorrhizal. Moreover, Myosotis sparsiflora (Boraginaceae) and Limosella aquatica (Scrophulariaceae) were also found not to form AM symbiosis.

Dark septate endophytes (DSE) were found in 15 plant species, both in the roots colonized by AMF and devoid of AM. The mean frequency of DSE occurrence in roots $\left(\mathrm{F}_{\mathrm{DSE}} \%\right)$ was low and ranged from $2.1 \%$ in Cnidum dubium to $58.4 \%$ in Allium angulosum (Table 2). The abundance of DSE in roots was low in all plant species.
Only single hyphae, accompanied sporadically by sclerotia, were found in the rhizodermis and outer cortex.

The sporangia of Olpidium spp. were found in ten plant species. The frequency of occurrence of these structures $\left(\mathrm{F}_{\mathrm{Olp}} \%\right)$ varied from $1.1 \%$ in Chaiturus marrubiastrum and Cirsium canum to $70 \%$ in Myosotis sparsiflora (Table 2). The abundance of sporangia in roots was low in all the plant species. Only single sporangia were found in the rhizodermis.

No significant correlation between root colonization by AMF or fungal endophytes and river corridor-specificity index of studied RCP was found (Table 3).

The presence of AMF in the river corridor soils

The spores of AMF were only found in 18 out of 56 trap cultures established from the soils collected in the river corridor habitats. In 15 trap cultures, a single fungal species was found, and three cultures contained two taxa. In total, the spores of six AMF species were isolated. In addition, one spore morphotype with glomoid spores similar to those of Diversispora spp. was found. The spores of Septoglomus constrictum were most frequently isolated and were present in eight cultures. In contrast, Funneliformis mosseae, Diversispora sp. and Rhizophagus irregularis were found in single cultures (Table 1).

Soil chemical properties

The comparison of means and standard errors of means of soil chemical properties revealed differences between soils typical of particular species or groups of species representing certain types of habitat (Table 4). In some cases, considerable differences in soil parameters between stations of a given species were also observed.

Soil $\mathrm{pH}$ at sites where plant material was collected ranged from 5.4 (in the case of Leymus arenarius) to 7.8 (for samples from under Sisymbrium strictissimum). The highest $\mathrm{pH}$ was usually observed for tall-herbs typical of watercourse veils developing along the river. The lowest total nitrogen, organic carbon and organic matter contents were recorded for Aethusa cynapioides, whereas the highest values of these three parametres were observed in soils from under Cnidium dubium. Generally, meadow species grew on soil with the highest total nitrogen, organic carbon and organic matter contents in the study area. The $\mathrm{C} / \mathrm{N}$ value ranged between 10.5 (for soil from under Eryngium planum) and 15.8 (for soil from under Myosotis sparsiflora). The lowest contents of plant-available phosphorus and potassium were observed for sandy soils (mostly soil from under Leymus arenarius and Petasites spurius) whereas the soils with the highest contents of the two substances were those collected from under the root systems 


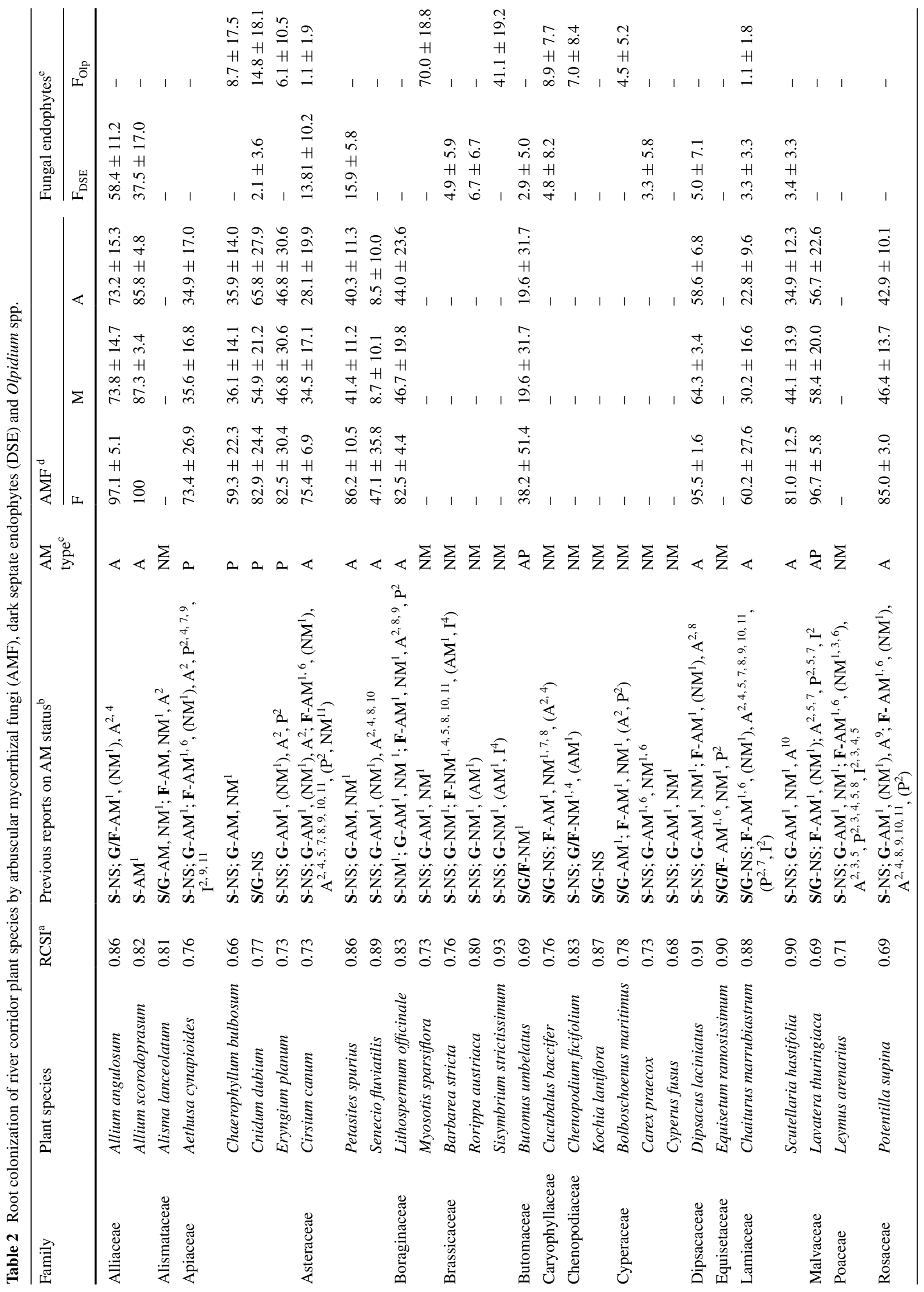




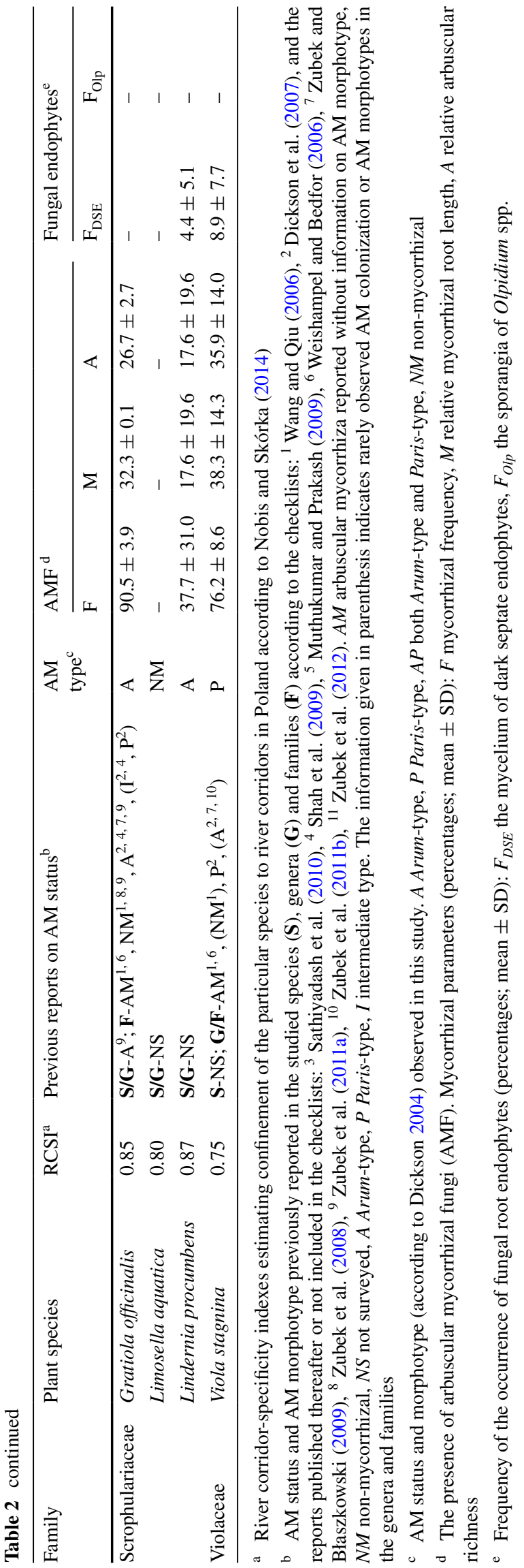

of plants representing different types of habitats. Similar trends were also found for major exchangeable cations $\left(\mathrm{K}^{+}, \mathrm{Na}^{+}, \mathrm{Mg}^{2+}\right.$ and $\left.\mathrm{Ca}^{2+}\right)$.

The Spearman's rank correlation coefficients confirmed medium correlations between root colonization of RCP species by DSE and the contents of total nitrogen and organic carbon as well as soil organic matter (Table 3). Moreover, root colonization of RCP by Olpidium spp. correlated significantly with the plant-available potassium and $\mathrm{Mg}^{2+}$ contents, as well as $\mathrm{pH}$ value, but these correlations were rather weak. No statistically significant correlation between root colonization of RCP by AMF and soil parameters analyzed was found (Table 3 ).

\section{Discussion}

In this paper, the detailed report on the occurrence of both AMF and fungal endophytes in roots of 33 plant species belonging to 18 families and confined to river corridors in Central Europe is presented. To our knowledge, the AM status of 26 plant species and seven genera is reported for the first time (see Table 2). The presence of AM in Allium scorodoprasum and Gratiola officinalis is consistent with the literature data. Butomus umbelatus and Lithospermum officinale, being reported earlier as non-mycorrhizal, were recognized in our studies as colonized by AMF. The roots of Bolboschoenus maritimus were devoid of AMF, contrary to previous reports. Alisma lanceolatum and Equisetum ramosissimum were also found not to form AM whereas, in earlier research, these species were observed to be both non-mycorrhizal and associated with AMF (Dickson et al. 2007; Wang and Qiu 2006; Zubek et al. 2011a).

Nineteen of the studied plant species formed AM associations. AMF mycelium was not found in the root systems of 14 plants. Most of these non-mycorrhizal species belong to Brassicaceae, Caryophyllaceae, Chenopodiaceae and Cyperaceae, that are generally accepted as conventionally AMF non-host families (Smith and Read 2008; Wang and Qiu 2006). In addition, Alisma lanceolatum (Alismataceae), Leymus arenarius (Poaceae), Equisetum ramosissimum (Equisetaceae), Myosotis sparsiflora (Boraginaceae) and Limosella aquatica (Scrophulariaceae) were also found not to form AM symbiosis. This may be due to the lack of AMF propagules in the sites of these plants. This seems to be especially the case for Leymus arenarius, Equisetum ramosissimum and Limosella aquatica as in the trap cultures established with soils collected from under the root systems of these plants no AMF spores were found. However, in the case of Alisma lanceolatum and Myosotis sparsiflora the spores were found in the trap cultures. This might indicate that the absence of AMF propagules in the soil was not the reason for the lack of mycorrhizae. The first possible 
Table 3 Spearman's rank correlation coefficients between root colonization of river corridor plant species by arbuscular mycorrhizal fungi/fungal endophytes and particular soil parameters/river corridor-specificity index

\begin{tabular}{|c|c|c|c|c|c|c|c|c|c|c|c|c|}
\hline & $\mathrm{pH}$ & $\mathrm{N}(\%)$ & $\mathrm{C}(\%)$ & Organic matter $(\%)$ & $\mathrm{C} / \mathrm{N}$ & $\mathrm{K}_{2} \mathrm{O}$ & $\mathrm{P}_{2} \mathrm{O}_{5}$ & $\mathrm{~K}^{+}$ & $\mathrm{Na}^{+}$ & $\mathrm{Ca}^{+}$ & $\mathrm{Mg}^{2+}$ & RCSI \\
\hline $\mathrm{F}_{\mathrm{AMF}} \%$ & -0.14 & 0.27 & 0.27 & 0.28 & -0.08 & 0.02 & -0.13 & -0.03 & 0.16 & 0.23 & 0.20 & -0.10 \\
\hline $\mathrm{M}_{\mathrm{AMF}} \%$ & -0.16 & 0.34 & 0.32 & 0.34 & -0.16 & 0.09 & -0.07 & 0.04 & 0.25 & 0.31 & 0.27 & -0.15 \\
\hline $\mathrm{A}_{\mathrm{AMF}} \%$ & -0.16 & 0.33 & 0.32 & 0.33 & -0.16 & 0.09 & 0.07 & 0.04 & 0.25 & 0.32 & 0.29 & -0.18 \\
\hline $\mathrm{F}_{\mathrm{DSE}} \%$ & -0.32 & $0.52 *$ & $0.54 *$ & $0.53 *$ & -0.04 & 0.02 & 0.10 & 0.05 & 0.18 & 0.26 & 0.22 & -0.25 \\
\hline $\mathrm{F}_{\mathrm{Olp}} \%$ & $0.37 *$ & 0.14 & 0.07 & 0.08 & -0.22 & $0.36 *$ & 0.21 & 0.34 & -0.01 & 0.23 & $0.37 *$ & -0.20 \\
\hline
\end{tabular}

For explanation of abbreviation, see Table 1 or the main text. Correlation coefficients greater than 0.5 are shown in bold

* Statistically significant $(P \leq 0.001)$

explanation for the absence of AM in the two species may be the lack of functional need for mycorrhizal association in these particular edaphic conditions, e.g. due to sufficient soil nutrient contents. This supposition seems to be confirmed mostly by the chemical properties of soils from under Myosotis sparsiflora (Table 4), however, the statistical analysis performed indicated no significant correlation between root colonization of RCP species by AMF and particular soil parameters. On the other hand, there is increasing evidence for some degree of physical and functional specificity in the symbiosis (Smith and Read 2008; Wubet et al. 2006). Therefore, if some AMF species are required for particular plants, the lack of compatible fungal symbionts in the soil may also be a reason for the absence of root colonization. Such a situation might occur, in particular, in river corridor habitats such as those characterized by rather low AMF species diversity, as it was shown in our studies (Table 1). In the studies by Błaszkowski et al. (2002); Zubek et al. (2008) and Zubek et al. (2009) on AMF species richness conducted in more stable plant communities in Southern Poland, 22, 20 and 15 AMF species, respectively, were found. Moreover, Kivlin et al. (2011), based on a synthesis of published DNA sequences, revealed that natural ecosystems harbor, on average, 15-30 AMF species.

AMF species found in the present study commonly occur in Poland and also have wide distribution in the world (Błaszkowski 2012; Błaszkowski et al. 2012). Although AMF spores were found in only $32 \%$ of the trap cultures established with the soils collected from under ten plant species, the AMF propagules were present in more sites as mycorrhizal colonization was found in the roots of 19 plant species. The establishment of trap cultures frequently stimulates sporulation of AMF and reveals species that produce spores either seasonally or not at all in natural habitats (Stutz and Morton 1996). Nevertheless, some AMF may, in contrast, not grow or produce spores in a laboratory probably as a result of high ecological (environmental) differences which may be owing to either edaphic conditions or the aforementioned AMF-host plant specificity (Zubek et al. 2013).
Floods typical of river corridors may cause significant reduction of gas exchange especially underground and can promote soil erosion. These usually result in decrease in survival or establishment of many plant species causing simultaneous reduction of plant cover, but it can also influence soil microorganisms, including AMF. Variable soil moisture in river valleys is undoubtedly also important for the occurrence of different organisms (e.g. Hensgen et al. 2011). We observed the presence of AMF in the majority of river valley sites under study, as revealed by both the observation of fungi colonizing roots and the presence of their spores in the trap cultures. Our result is in line with literature data, which confirms the adaptation of AMF to harsh conditions. The presence of AMF has been observed in wet habitats (Ingham and Wilson 1999; Kołaczek et al. 2013; Weishampel and Bedfor 2006). The colonization of roots was found even in plants experiencing flooded conditions (Bohrer et al. 2004; Miller 2000; Stevens et al. 2011). The presence of AMF communities has been also found in diverse habitats exposed to extreme drought stress (AlYahya'ei et al. 2011; Chaudhry et al. 2005). Furthermore, it was shown that mechanical soil disturbance reduced AMF propagule abundance (Gosling et al. 2006; Kabir 2005), spore numbers (Galvez et al. 2001) and species/phylotype richness (Brito et al. 2012; Schnoor et al. 2011). Although Jansa et al. $(2002,2003)$ found that soil disturbance had generally negative effect on the abundance of some AMF species, relatively high AMF diversity was still detected in disturbed soils. Some AMF species were more tolerant to the disturbance due to differences in life strategies among fungal taxa, namely disparate growth patterns and propagules (Schnoor et al. 2011).

The mycelia of dark septate endophytes (DSE) were found in 15 plants. DSE co-occurred with AMF in the roots of several species, but also occurred in plants that were nonmycorrhizal. DSE represent a taxonomically diverse group of fungi. They are frequently encountered root-inhabiting fungi of numerous plant species from a wide range of terrestrial ecosystems (Newsham 2011; Weishampel and Bedfor 2006). The effects of these endophytes on plants are 


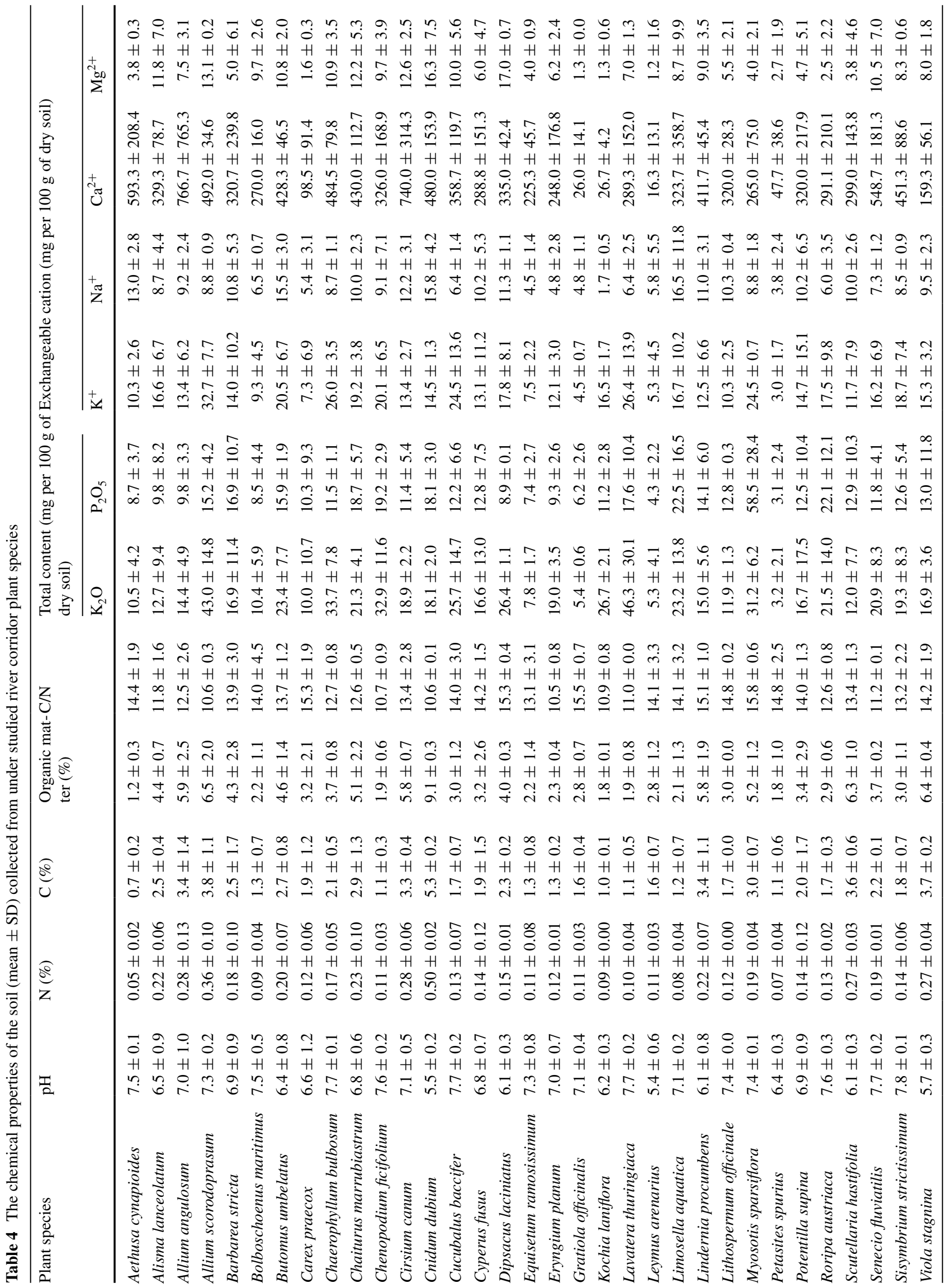


diverse and may depend on the host species, fungal taxa or strains, and environmental conditions (Andrade-Linares et al. 2011; Mandyam and Jumpponen 2005; Mandyam et al. 2012; Newsham 2011; Wu et al. 2010). In addition to the presence of AMF and DSE mycelia in the roots of RCP under study, the sporangia of Olpidium spp. were found sporadically in ten species. The taxonomic position of this group of fungi, traditionally placed in Chytridiomycota, is currently considered to be uncertain (Hibbett et al. 2007). Nevertheless, their biology has been well-documented. Several species from the Olpidium genus were found to be symptomless root parasites and also the vectors of plant viruses (Webster and Weber 2007; Verchot-Lubicz 2003). The correlation between root colonization of RCP species by DSE and Olpidium spp. and some soil chemical properties is not apparent and requires further investigations.

In conclusion, the obtained results only to some extent confirm our supposition that species confined to river corridors do not form AM or form it rarely and that the degree of colonization of their roots is low due to the lack of AMF propagules in their habitats. AMF are believed to colonize roots of the great majority (ca. $80 \%$ ) of vascular plants in the world (Perotto et al. 2013; Smith and Read 2008). Our study of 33 RCP species indicated that 14 of the examined species were non-mycorrhizal. Although 19 species were mycorrhizal and most of them were characterized by high mycorrhizal frequency and also colonization rate, the possibility that some of them are not dependent on AMF and do not benefit from this symbiotic association in stable plant-AMF communities outside river corridors can not be excluded. It is worth noting that research carried out by Donath et al. (2003) showed that in the case of some RCP favorable site conditions do not guarantee their restoration success. What is more, in the experimental studies, Fischer et al. (2010) showed that species more confined to river corridor areas are less able to take advantage of more benign conditions (i.e., absence of flooding and more favorable soil properties) typical for non-river corridor habitats than the species of wide distributional range.

Among 85 vascular plant species which are considered to be confined to river corridors in Poland (Nobis and Skórka 2014), but not studied during our research, there are some which are not associated with AMF because they are parasitic plants (e.g. Cuscuta lupuliformis) or have no roots (e.g. Salvinia natans, Wolffia arrhiza). Many other (e.g. Arabis planisiliqua, Cardamine parviflora, Cerasitum dubium, Chenopodium acerifolium, Corrigiola litoralis, Dichostylis mischeliana, Erysimum hieracifolium, Rumex paluster, Rumex ucrainicus, Silene tatarica) with high probability are non-mycorrhizal as they represent families or genera that are generally considered as non-mycorrizal (Smith and Read 2008; Wang and Qiu 2006). Therefore, the final percentage of non-mycorrhizal species in the group of RCP may be large and not accidental.

It must be emphasized that for a particular river corridor species its corridor-like distribution can be determined by the combination of certain abiotic and biotic variables, but because the group of plants in question is very heterogenous, it is unlikely that a single hypothesis could explain the river corridor distribution pattern (Burkart 2001). It is known that some non-mycorrhizal plants may have significantly lower competitive ability in comparison with those which are mycorrhizal (Smith and Read 2008). Therefore, it is probable that the river corridor species under study which turned out to be non-mycorrhizal are simply outcompeted outside river valleys. This supposition, however, requires confirmation. Further studies (including experimental) on the role of AMF and other endophytes in RCP distribution are thus needed.

Acknowledgments We would like to express our gratitude to $\mathrm{dr}$ hab. Piotr Mleczko for his comments on the manuscript. This study was supported by Polish Ministry of Science and Higher Education (grant no. NN305 202735), Institute of Botany, Jagiellonian University (grant no. K/ZDS/004143), and Polish National Centre of Science (grants no. 2012/05/B/NZ8/00498 and 2012/07/N/NZ8/02363).

Open Access This article is distributed under the terms of the Creative Commons Attribution License which permits any use, distribution, and reproduction in any medium, provided the original author(s) and the source are credited.

\section{References}

Al-Yahya'ei MN, Oehl F, Vallino M, Lumini E, Redecker D, Wiemken A, Bonfante P (2011) Unique arbuscular mycorrhizal fungal communities uncovered in date palm plantations and surrounding desert habitats of Southern Arabia. Mycorrhiza 21:195-209. doi:10.1007/s00572-010-0323-5

Andersson E, Nilsson C (2002) Temporal variation in the drift of plant litter and propagules in a small boreal river. Freshwater Biol 47:1674-1684. doi:10.1046/j.1365-2427.2002.00925.x

Andrade-Linares DR, Grosch R, Restrepo S, Krumbein A, Franken P (2011) Effects of dark septate endophytes on tomato plant performance. Mycorrhiza 21:413-422. doi:10.1007/s00572-010-0351-1

Andres C, Westhus W (2000) Artenhilfsmaßnahmen für hochgradig gefährdete Stromtalpflanzen. Landschpfl Natschutz Thüring 37:33-38

Ascherson P (1859) Pflanzengeographische Studien über die Flora der Mark Brandenburg. II. Über die dem Alluvium, Diluvium (und den älteren Bildungen) eigentümlichen Gefäßpflanzen (mit Pflanzenverzeichnis). Verh Bot Vereins Prov Brandenburg 1:27-41

Błaszkowski J (2012) Glomeromycota. W. Szafer Institute of Botany Polish Academy of Sciences, Kraków

Błaszkowski J, Tadych M, Madej T (2002) Arbuscular mycorrhizal fungi (Glomales, Zygomycota) of the Błędowska Desert, Poland. Acta Soc Bot Pol 71:71-85

Błaszkowski J, Kovács GM, Gáspár BK, Balázs TK, Buscot F, Ryszka P (2012) The arbuscular mycorrhizal Paraglomus majewskii sp. nov. represents a distinct basal lineage in Glomeromycota. Mycologia 104:148-156. doi:10.3852/10-430 
Bohrer KE, Friese CF, Amon JP (2004) Seasonal dynamics of arbuscular mycorrhizal fungi in differing wetland habitats. Mycorrhiza 14:329-337. doi:10.1007/s00572-004-0292-7

Brito I, Goss MJ, de Carvalho M, Chatagnier O, van Tuinen D (2012) Impact of tillage system on arbuscular mycorrhiza fungal communities in the soil under Mediterranean conditions. Soil Till Res 121:63-67. doi:10.1016/j.still.2012.01.012

Burkart M (1995) Juncus atratus in Nordostdeutschland. Verh Bot Vereins Berlin und Brandenburg 128:83-107

Burkart M (2001) River corridor plants (Stromtalpflanzen) in Central European lowland: a review of poorly understood plant distribution pattern. Global Ecol Biogeogr 10:449-468. doi:10.1046/j.1466-822x.2001.00270.x

Chaudhry MS, Batool Z, Khan AG (2005) Preliminary assessment of plant community structure and arbuscular mycorrhizas in rangeland habitats of Cholistan desert, Pakistan. Mycorrhiza 15:606611. doi:10.1007/s00572-005-0002-0

Dickson NS (2004) The Arum-Paris continuum of mycorrhizal symbioses. New Phytol 163:187-200. doi:10.1111/j.1469-8137.2004.01095.x

Dickson S, Smith A, Smith SE (2007) Structural differences in arbuscular mycorrhizal symbioses: more than 100 years after Gallaud, where next? Mycorrhiza 17:375-393. doi:10.1007/ s00572-007-0130-9

Donath TW, Holzel N, Otte A (2003) The impact of site conditions and seed dispersal on restoration success in alluvial meadows. Appl Veg Sci 6:13-22. doi:10.1111/j.1654-109X.2003. tb00560.x

Egner H, Riehm H, Domingo WR (1960) Untersuchungen über die chemische Bodenanalyse als Grundlage für die Beurteilung des Nährstoffzustandes der Boden. Kungl Lantbrukshögskolans Annaler 26:199-215

Fischer W (1996) Die Stromtalpflanzen Brandenburgs. Untere Havel Naturkdl Ber 5:4-13

Fischer M, Burkart M, Pasqualetto V, van Kleunen M (2010) Experiment meets biogeography: plants of river-corridor distribution are not more stress-tolerant but benefit less from more benign conditions elsewhere. J Plant Ecol 3:149-155. doi:10.1093/jpe/rtq013

Galvez L, Douds DD, Drinkwater LE, Wagoner P (2001) Effect of tillage and farming system upon VAM fungus populations and mycorrhizas and nutrient uptake of maize. Plant Soil 228:299 308. doi:10.1023/A:1004810116854

Gams H (1927) Labiatae. In: Hegi G (ed) Illustrierte Flora von MittelEuropa, vol 4. Lehmanns, München, pp 2255-2548

Gerdemann JW, Nicolson TH (1963) Spores of mycorrhizal Endogone species extracted from soil by wet sieving and decanting. Trans Brit Mycol Soc 46:235-244. doi:10.1016/ S0007-1536(63)80079-0

Gosling P, Hodge A, Goodlass G, Bending GD (2006) Arbuscular mycorrhizal fungi and organic farming. Agric Ecosyst Environ 113:17-35. doi:10.1016/j.agee.2005.09.009

Hensgen F, Albrecht C, Donath TW, Otte A, Eckstein RL (2011) Distribution of gastropods in floodplain compartments and feeding preferences for river corridor plant species: Is there an effect of gastropod herbivory on the distribution of river corridor plants? Flora 206:534-543. doi:10.1016/j.flora.2011.01.002

Hibbett DS, Binder M, Bischoff JF, Blackwell M, Cannon PF et al (2007) A higher-level phylogenetic classification of the Fungi. Mycol Res 111:509-547. doi:10.1016/j.mycres.2007.03.004

Ingham ER, Wilson MV (1999) The mycorrhizal colonization of six wetland plant species at sites differing in land use history. Mycorrhiza 9:233-235. doi:10.1007/s005720050272

Jansa J, Mozafar A, Anken T, Ruh R, Sanders IR, Frossard E (2002) Diversity and structure of AMF communities as affected by tillage in a temperate soil. Mycorrhiza 12:225-234. doi:10.1007/ s00572-002-0163-Z
Jansa J, Mozafar A, Kuhn G, Anken T, Ruh R, Sanders IR, Frossard E (2003) Soil tillage affects the community structure of mycorrhizal fungi in maize roots. Ecol Appl 13:1164-1176

Jentsch H, Seitz B (1997) Stromtalpflanzen im Spreewald. Verh Bot Vereins Berlin Brandenburg 129:25-36

Jumpponen A (2001) Dark septate endophytes-are they mycorrhizal? Mycorrhiza 11:207-211. doi:10.1007/s005720100112

Kabir Z (2005) Tillage or no-tillage: impact on mycorrhizae. Can J Plant Sci 85:23-29. doi:10.4141/P03-160

Kivlin SN, Hawkes CV, Treseder KK (2011) Global diversity and distribution of arbuscular mycorrhizal fungi. Soil Biol Biochem 43:2294-2303. doi:10.1016/j.soilbio.2011.07.012

Kołaczek P, Zubek S, Błaszkowski J, Mleczko P, Margielewski W (2013) Erosion or plant succession-How to interpret the presence of arbuscular mycorrhizal fungi (Glomeromycota) spores in pollen profiles collected from mires. Rev Palaeobot Palyno 189:29-37. doi:10.1016/j.revpalbo.2012.11.006

Kornerup A, Wanscher JH (1983) Methuen handbook of colour, 3rd edn. Eyre Methuen, London

Loew E (1879) Über Perioden und Wege ehemaliger Pflanzenwanderungen im norddeutschen Tieflande. Linnaea 42:511-660

Mandyam K, Jumpponen A (2005) Seeking the elusive function of the root-colonising dark septate endophytic fungi. Stud Mycol 53:173-189. doi:10.3114/sim.53.1.173

Mandyam K, Fox C, Jumpponen A (2012) Septate endophyte colonization and host responses of grasses and forbs native to a tallgrass prairie. Mycorrhiza 22:109-119. doi:10.1007/s00572-011-0386-y

Miller SP (2000) Arbuscular mycorrhizal colonization of semiaquatic grasses along a wide hydrologic gradient. New Phytol 145:145155. doi:10.1046/j.1469-8137.2000.00566.x

Mirek Z, Piękoś-Mirkowa H, Zając A, Zając M (eds) (2002) Flowering plants and pteridophytes of Poland. A checklist. Biodiversity of Poland, vol. 1. W. Szafer Institute of Botany, Polish Academy of Sciences, Kraków

Mocek M, Drzymała S (2010) Geneza, analiza i klasyfikacja gleb. Wydawnictwo Uniwersytetu Przyrodniczego w Poznaniu, Poznań

Müller-Stoll WR, Fischer W, Krausch HD (1962) Verbreitungskarten brandenburgischer Leitpflanzen. Vierte Reihe. Wiss Z Pädagog Hochschule Potsdam, Math-Naturwiss Reihe 7:95-150

Muthukumar T, Prakash S (2009) Arbuscular mycorrhizal morphology in crops and associated weeds in tropical agro-ecosystems. Mycoscience 50:233-239. doi:10.1007/S10267-008-0475-8

Newsham KK (2011) A meta-analysis of plant responses to dark septate root endophytes. New Phytol 190:783-793. doi:10.1111/j.1469-8137.2010.03611.x

Nilsson C, Brown RL, Jansson R, Merritt DM (2010) The role of hydrochory in structuring riparian and wetland vegetation. Biol Rev 85:837-858. doi:10.1111/j.1469-185X.2010.00129.x

Nobis A, Skórka P (2014) River corridor plants revisited: what drives their unique distribution patterns? Plant Biosyst. doi:10.1080/112 63504.2014.972999

Omar MB, Bolland L, Heather WA (1979) A permanent mounting medium for fungi. Bull Brit Mycol Soc 13:31-32

Perotto S, Angelini P, Bianciotto V, Bonfante P, Girlanda M, Kull T et al (2013) Interactions of fungi with other organisms. Plant Biosyst 147:208-218

Phillips J, Hayman DS (1970) Improved procedures for clearing roots and staining parasitic and vesicular-arbuscular mycorrhizal fungi for rapid assessment of infection. Trans Brit Mycol Soc 55:158-161

Pyšek P, Prach K (1994) How important are rivers for supporting plant invasions? In: Waal LC, Child LE, Wade PM, Brock $\mathrm{JH}$ (eds) Ecology and management of invasive riverside plants. Wiley, Chichester, pp 19-26

Redecker D, Schüßler A, Stockinger A, Stürmer SL, Morton JB, Walker C (2013) An evidence-based consensus for the 
classification of arbuscular mycorrhizal fungi (Glomeromycota). Mycorrhiza 23:515-531. doi:10.1007/s00572-013-0486-y

Sathiyadash K, Muthukumar T, Uma E (2010) Arbuscular mycorrhizal and dark septate endophyte fungal associations in South Indian grasses. Symbiosis 52:21-32. doi:10.1007/s13199-010-0096-9

Schnoor TK, Lekberg Y, Rosendahl S, Olsson PA (2011) Mechanical soil disturbance as a determinant of arbuscular mycorrhizal fungal communities in semi-natural grassland. Mycorrhiza 21:211220. doi:10.1007/s00572-010-0325-3

Schüßler A, Walker C (2010) The Glomeromycota: a species list with new families and new genera. In: Schüßler A, Walker C, Gloucester. Published in libraries at The Royal Botanic Garden Edinburgh, The Royal Botanic Garden Kew, Botanische Staatssammlung Munich, and Oregon State University

Shah MA, Reshi Z, Khasa D (2009) Arbuscular mycorrhizal status of some Kashmir Himalayan alien invasive plants. Mycorrhiza 20:67-72. doi:10.1007/s00572-009-0258-x

Smith SE, Read DJ (2008) Mycorrhizal symbiosis. Elsevier Academic Press, London

Stevens KJ, Wall CB, Janssen JA (2011) Effects of arbuscular mycorrhizal fungi on seedling growth and development of two wetland plants, Bidens frondosa L., and Eclipta prostrata L., grown under three levels of water availability. Mycorrhiza 21:279-288. doi:10.1007/s00572-010-0334-2

Stutz JC, Morton JB (1996) Successive pot cultures reveal high species richness of arbuscular mycorrhizal fungi in arid ecosystems. Can J Bot 74:1883-1889. doi:10.1139/b96-225

Trouvelot A, Kough JL, Gianinazzi-Pearson V (1986) Mesure du taux de mycorhization VA d'un systeme radiculaire. Recherche de methodes d'estimation ayant une signification fonctionnelle. In: Gianinazzi-Pearson V, Gianinazzi S (eds) Physiological and genetical aspects of mycorrhizae. INRA, Paris, pp 217-221

Vent W, Benkert D (1984) Verbreitungskarten brandenburgischer Pflanzenarten. 2. Reihe. Stromtalpflanzen (1). Gleditschia 12:213-238

Verchot-Lubicz J (2003) Soilborne viruses: advances in virus movement, virus induced gene silencing, and engineered resistance. Physiol Mol Plant Pathol 62:55-63. doi:10.1016/ S0885-5765(03)00040-7

Wang B, Qiu YL (2006) Phylogenetic distribution and evolution of mycorrhizas in land plants. Mycorrhiza 16:299-363. doi:10.1007/ s00572-005-0033-6
Webster J, Weber RWS (2007) Introduction to Fungi, 3rd edn. Cambridge University Press, New York, pp 145-148

Weishampel PA, Bedfor BL (2006) Wetland dicots and monocots differ in colonization by arbuscular mycorrhizal fungi and dark septate endophytes. Mycorrhiza 16:495-502. doi:10.1007/ s00572-006-0064-7

Wu L, Lv Y, Meng Z, Chen J, Guo S (2010) The promoting role of an isolate of dark-septate fungus on its host plant Saussurea involucrata Kar. et Kir. Mycorrhiza 20:127-135. doi:10.1007/ s00572-009-0268-8

Wubet T, Weiss M, Kottke I, Oberwinkler F (2006) Two threatened coexisting indigenous conifer species in the dry Afromontane forests of Ethiopia are associated with distinct arbuscular mycorrhizal fungal communities. Can J Bot 84:1617-1627. doi:10.1139/ b06-121

Zubek S, Błaszkowski J (2009) Medicinal plants as hosts of arbuscular mycorrhizal fungi and dark septate endophytes. Phytochem Rev 8:571-580

Zubek S, Turnau K, Błaszkowski J (2008) Arbuscular mycorrhiza of endemic and endangered plants from the Tatra Mts. Acta Soc Bot Pol 77:149-156

Zubek S, Błaszkowski J, Delimat A, Turnau K (2009) Arbuscular mycorrhizal and dark septate endophyte colonization along altitudinal gradients in the Tatra Mountains. Arct Antarct Alp Res 41:272-279

Zubek S, Błaszkowski J, Mleczko P (2011a) Arbuscular mycorrhizal and dark septate endophyte associations of medicinal plants. Acta Soc Bot Pol 80:285-292

Zubek S, Nobis M, Błaszkowski J, Mleczko P, Nowak A (2011b) Fungal root endophyte associations of plants endemic to the Pamir Alay Mountains of Central Asia. Symbiosis 54:139-149. doi:10.1007/s13199-011-0137-z

Zubek S, Błaszkowski J, Buchwald W (2012) Fungal root endophyte associations of medicinal plants. Nova Hedw 94:525-540. doi: 10.1127/0029-5035/2012/0024

Zubek S, Błaszkowski J, Seidler-Łożykowska K, Bąba W, Mleczko P (2013) Arbuscular mycorrhizal fungi abundance, species richness and composition under the monocultures of five medicinal plants. Acta Sci Pol Hortoru 12:127-141 